\title{
Pantoprazole Sodium Sesquihydrate Complexes: Synthesis, Characterization, Potentiometric Determination and DNA interaction
}

\author{
Y. M. ISSA ${ }^{1}$, W. H. HEGAZY ${ }^{2 *}$, W. N. EL-SAYED ${ }^{2,3}$ and H. I. AHMED ${ }^{2}$ \\ 'Department of Chemistry, Faculty of Science, Cairo University, Giza, Egypt. \\ ${ }^{2}$ Department of Chemistry, Faculty of Science, Suez University, Suez, Egypt \\ ${ }^{3}$ Chemistry Department, Faculty of Science and Arts, University of Jeddah, \\ Alkamel, Kingdom of Saudi Arabia. \\ *Corresponding author E-mail: wael.hegazy@ suezuniv.edu.eg \\ http://dx.doi.org/10.13005/ojc/320234
}

(Received: February 12, 2016; Accepted: March 09, 2016)

\begin{abstract}
The synthesis and characterization of solid complexes for pantoprazole sodium sesquihydrate (PNZ) with $\mathrm{Cd}(\mathrm{II}), \mathrm{Hg}(\mathrm{II})$ and $\mathrm{Zn}(\mathrm{II})$ metals in molar ratios $\mathrm{M}: \mathrm{L}=1: 2$ was studied. The complexes are stable in the solid state and are soluble only in DMF and DMSO. The metal complexes were characterized by elemental analysis, molar conductivity measurements, magnetic susceptibility, UV spectrophotometry, IR, Mass spectra, TGA/DTG analysis. Potentiometric measurements for these metal complexes were studied.
\end{abstract}

Keywords: Pantoprazole, complexes, potentiometry, Proton Pump Inhibitors, DNA interaction.

\section{INTRODUCTION}

Pantoprazole sodium sesquihydrate is benzimidazole derivative which have biological activity to inhibit gastric acid secretion ${ }^{1}$. Pantoprazole acts as good ligand as it has several coordination modes $^{2-4}$. Many drugs enhance its pharmacological and toxicological properties by their complexation with metal ions. $\mathrm{Cd}(\mathrm{II}), \mathrm{Hg}(\mathrm{II})$ and $\mathrm{Zn}(\mathrm{II})^{5}$. In this paper, several techniques were used to characterize the prepared pantoprazole complexes. DNA interaction of these complexes was given.

\section{EXPERIMENTAL}

\section{Solid complexes}

All complexes were prepared according to the following procedure. The pantoprazole ligand $(0.5 \mathrm{mmol})$ is dissolved in $10 \mathrm{~cm}^{3} \mathrm{H}_{2} \mathrm{O}$. The metal salt $(0.25 \mathrm{mmol})$ dissolved in $10 \mathrm{~cm}^{3} \mathrm{H}_{2} \mathrm{O}$ 
is added dropwise with continues stirring to the ligand solution. The formed precipitate was filtered, washed with hot water and dried. Synthesized solid complex were characterized by elemental analysis, IR, mass spectrometry, electrical conductivity, magnetic susceptibility, UV spectroscopy and thermal analysis.

\section{Physical measurements}

The electronic absorption spectra were obtained in $10^{-5} \mathrm{mo} / \mathrm{L}$ DMF solution in $1 \mathrm{~cm}$ quartz cell using Shimadzu-1601PC UV-Visible automatic recording spectro-photometer. The CHNS elemental analysis was estimated using Thermo Flasha Eager 300. The infrared spectra were recorded as $\mathrm{KBr}$ discs in the $400-4000 \mathrm{~cm}^{-1}$ range using perkin Elmer 1650 FT-IR instrument. TGA were obtained using a Shimazdu DTG-60H in a dynamic air atmosphere (30 $\mathrm{cm} \mathrm{min}-1$ ) at a heating rate of $10{ }^{\circ} \mathrm{C} \mathrm{min}^{-1}$. Conductivity of the dissolved complexes were carried out at room temperature on freshly prepared $10^{-3} \mathrm{~mol} / \mathrm{L}$ DMF solutions using Jenco Model 1671 Dual Display Bench Top instrument pH/ORP (redox)/conductive. Magnetic susceptibility measurements were carried out using the modified Gouy method ${ }^{6}$ on MSB-MK1 balance at room temperature using murcuru (II) tetrathiocyanatecobaltate(II). The effective magnetic moment $\mu_{\text {eff }}$, per metal atom was calculated from the expression $\mu_{\text {eff }}=2.83 \sqrt{ }$ x.T B.M., where $x$ is the molar susceptibility corrected using Pascal's constant for the diamagnetism of all atoms in the complexes. Mass spectra were done by AMD Intectra Gmb HDP10. Data system El/8 Kv spectrometer.

\section{Kinetic parameters}

In order to assess the influence of the structural properties of the ligand and the type of metal on thermal behavior of the complexes, the order $\mathrm{n}$ and the heat of activation $\mathrm{E}$ at the various decomposition stages were determined from TGA and DTG thermograms using the Coats-Redfern equations in the following form ${ }^{7}$.

$$
\begin{array}{r}
\ln \left[\frac{1-(1-\alpha)^{1-n}}{(1-n) T^{2}}\right] \\
=\ln \left(\frac{A R}{\beta E}\right)\left[1-\frac{2 R T}{E}\right]-\left(\frac{E}{2.303 R T}\right) \quad \text { for } n \neq 1 \\
\ln \left[-\frac{\ln (1-\alpha)}{T^{2}}\right]=\ln \left(\frac{A R}{\beta E}\right)\left[1-\frac{2 R T}{E}\right]-\left(\frac{E}{2.303 R T}\right) \quad \text { for } n=1
\end{array}
$$

Where: $\alpha$ is fraction of weight loss, $T$ is temperature $(\mathrm{K}), \mathrm{n}$ is order of reaction, $\mathrm{A}$ is preexponential factor, $\mathrm{R}$ is molar gas constant, $\mathrm{E}_{\mathrm{a}}$ is activation energy, â is heating rate.

The correlation factor $r$ is computed using the least squares method for equations (1) and (2). Linear curves were drawn for values equal $0.5,1$, $1.5,2,2.5$ and 3 . The value of $n$ which gave the best linear plot was chosen as the order parameter for the decomposition stage of interest and the heat of activation was calculated from its slope ${ }^{8,9}$.

The activation entropy $\Delta \mathrm{S}$, the activation enthalpy $\Delta \mathrm{H}$ and the free energy of activation $\Delta \mathrm{G}$ were calculated using the following equations:

$$
\begin{aligned}
& \Delta S=R \ln \left(\frac{A h}{K T}\right) \\
& \Delta H=E-R T \\
& \Delta G=\Delta H-T \Delta S
\end{aligned}
$$

$\mathrm{K}$ and $\mathrm{h}$ are the Boltzman's and Plank's constants.

\section{DNA Interaction}

All the experiments involving the binding of complexes with CT-DNA were carried out in double distilled water and adjusted to $\mathrm{pH} 7.2$. Absorption titration experiments were performed with ûxed concentrations of the compounds $\left(1 \times 10^{-4} \mathrm{~mol} / \mathrm{L}\right)$ with varying concentration of DNA (0-60 $\mu \mathrm{mol} / \mathrm{L})$. While measuring the absorption spectra, an equal amount of DNA was added to both the test solution and the reference solution to eliminate the absorbance of DNA itself. The values of the intrinsic binding constants $\mathrm{K}_{\mathrm{b}}$ were calculated by regression analysis using the equation ${ }^{10}$.

$$
[D N A] /\left(\varepsilon_{a}-\varepsilon_{f}\right)=[D N A] /\left(\varepsilon_{b}-\varepsilon_{f}\right)+1 / K b\left(\varepsilon_{a}-\varepsilon_{f}\right)
$$

where [DNA] is the concentration of CT-DNA in base pairs and $\varepsilon_{a}, \varepsilon_{f}$ and $\varepsilon_{b}$ are molar absorbitivities of the apparent, free and bound metal complex, respectively and $\mathrm{K}_{\mathrm{b}}$ is the equilibrium binding constant. In the plots of [DNA] $/\left(\varepsilon_{\mathrm{a}}-\varepsilon_{\mathrm{f}}\right)$ versus [DNA], $\mathrm{K}_{\mathrm{b}}$ is given by the ratio of slope to the intercept. 


\section{Potentiometric study}

All materials employed in the present investigation were of A.R. grade products. [amino succinic acid] $\mathrm{C}_{4} \mathrm{H}_{7} \mathrm{NO}_{2}$ (Aspartic acid), [2-aminopropanoic acid] $\mathrm{C}_{3} \mathrm{H}_{7} \mathrm{NO}_{2}$ (Alanine), [2-amino-3imidazole propanoic acid] $\mathrm{C}_{6} \mathrm{H}_{9} \mathrm{~N}_{3} \mathrm{O}_{2}$ (Histidine), $\mathrm{C}_{4} \mathrm{H}_{9} \mathrm{NO}_{3}$ (Threonine), $\mathrm{C}_{3} \mathrm{H}_{7} \mathrm{NSO}_{2}$ (Cysteine), and $\mathrm{C}_{9} \mathrm{H}_{11} \mathrm{NO}_{2}$ (Phenylalanine), were purchased from Sigma-Aldrich Company and were used without purification. To account for preparation of metal ion amino acid solutions of exactly a 1:1 ratio, we also determined, by potentiometric $\mathrm{pH}$ titration, the molecular weight of these amino acids.

\section{RESULTS AND DISCUSSIONS}

\section{Elemental analysis}

The elemental analyses of the solid complexes of pantoprazole are recorded in Table
(1). It is clear that the formula of the $\mathrm{Hg}^{2+}$ and $\mathrm{Zn}^{2+}$ complexes may be represented as $\left[\mathrm{M}(\mathrm{PNZ})\left(\mathrm{H}_{2} \mathrm{O}\right)\right.$ $\mathrm{Cl}] \mathrm{H}_{2} \mathrm{O}$, while $\mathrm{Cd}^{2+}$ complex is represented as $\left[\mathrm{Cd}(\mathrm{PNZ})_{2}\left(\mathrm{H}_{2} \mathrm{O}\right)_{2}\right] \mathrm{H}_{2} \mathrm{O}$.

\section{Molar conductivity measurements}

The complexes were dissolved in DMF and the molar conductivities of $10^{-3} \mathrm{~mol} / \mathrm{L}$ of their solutions at $25 \pm 2^{\circ} \mathrm{C}$ were measured. Table (2) shows the molar conductance values of the complexes. It is concluded from the results that the complexes are found to have molar conductance values of $6-18.8$ $\Omega^{-1} \mathrm{~cm}^{2} \mathrm{~mol}^{-1}$ indicating that these complexes are non-electrolytes. It also, indicates the bonding of the chloride anion to the metal ions.

\section{Electronic spectra measurements and magnetic susceptibility}

The UV-Visible spectra of the ligand

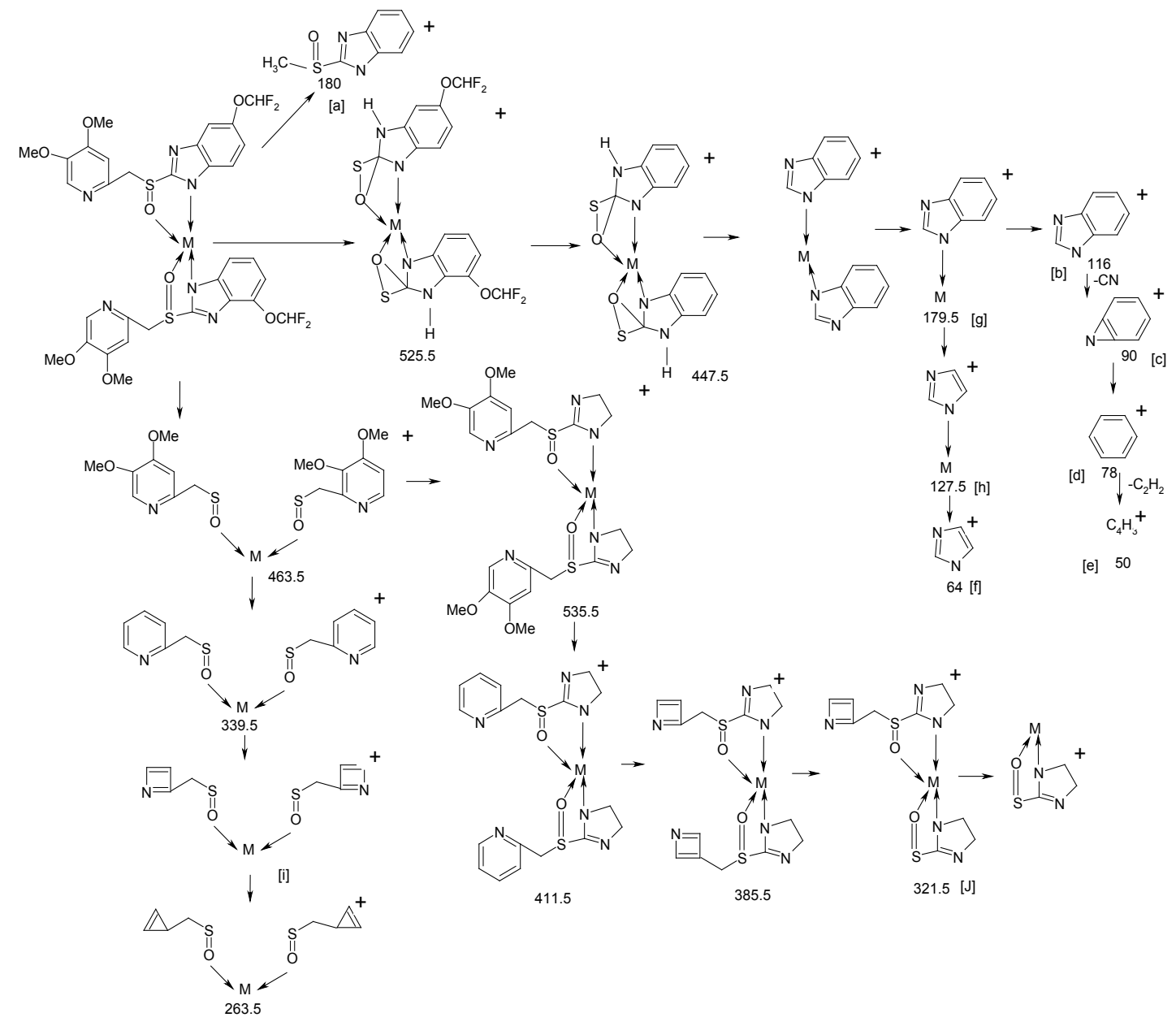

Scheme 1: Fragmentation pattern for PNZ-complexes 
and its complexes were recorded in DMF at room temperature. The electronic spectrum of ligand showed only one intense band at $34246 \mathrm{~cm}^{-1}$, which was assigned to $\mathrm{n} \rightarrow \pi^{*}$ transition of the $\mathrm{C}=\mathrm{N}$ chromophore. The complexes of $\mathrm{Zn}(\mathrm{II}), \mathrm{Hg}$ (II) and $\mathrm{Cd}(\mathrm{II})$ is diamagnetic and have only one peak in the UV region. According to the empirical formula, $\mathrm{Cd}(\mathrm{II})$ complex has an octahedral geometry while both $\mathrm{Zn}(\mathrm{II})$ and $\mathrm{Hg}(\mathrm{II})$ have tetrahedral geometry.

\section{IR spectra and mode of bonding}

IR spectra for the ligand and its complexes are shown in Table (3). In the free ligand, the band at $1373 \mathrm{~cm}^{\prime \prime} 1$ is assigned to $v(\mathrm{C}-\mathrm{N})$. After complexation, this band is shifted to higher frequency in the three complexes. Shifting of the $v(\mathrm{C}-\mathrm{N})$ vibration is due to $\mathrm{C}-\mathrm{N} \rightarrow \mathrm{M}^{2+}$ coordination ${ }^{11}$. Characteristic band at $3498 \mathrm{~cm}^{\mathrm{\prime \prime}}$ is assigned to presence of water in the ligand structure; similarly presence of coordinated water is confirmed by the presence of band at $3372-3440 \mathrm{~cm}^{\text {"1112 }}$. Coordinated water molecule is also noticed as a weak band at $815-820 \mathrm{~cm}^{\prime \prime 1}$ due to rocking mode while band at $450-630 \mathrm{~cm}^{\prime 11}$ indicated

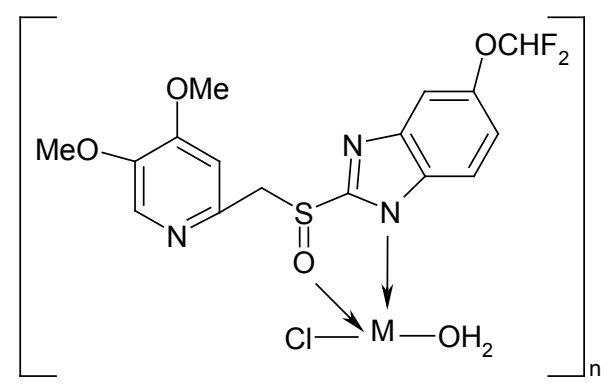

$\mathrm{OH}_{2}$

$M=H g(I I), Z n(I I)$

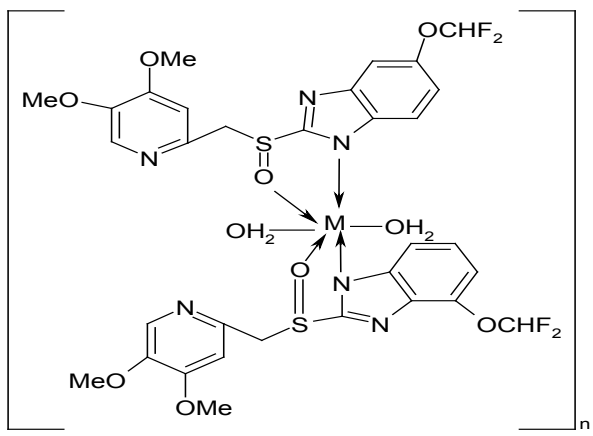

$2 \mathrm{OH}_{2}$

Scheme 2: Complexes of Cd-PNZ, Hg-PNZ and Zn-PNZ the presence of water of crystallization ${ }^{13}$. In addition, IR spectrum of the ligand revealed a sharp band at $1035 \mathrm{~cm}^{\prime \prime 1}$ due to $v(\mathrm{~S}=0)$ of side chain, which is shifted to higher frequency after complexation in all complexes, suggesting that oxygen atom of the side chain also contributes to the complexation. New bands appeared in the spectra of the complexes at $633-733 \mathrm{~cm}^{\prime \prime 1}$, corresponding to $\mathrm{O} \rightarrow \mathrm{M}$ and $410-540$ $\mathrm{cm}^{-1}$ due to the $\mathrm{N} \rightarrow \mathrm{M}$ vibrations which support the involvement of $\mathrm{N}$ and $\mathrm{O}$ atoms in complexation with metal ions under investigation ${ }^{14}$. Characteristic strong band at $1486 \mathrm{~cm}^{-1}$ is assignable to the stretching vibration of aromatic $\mathrm{C}=\mathrm{N}$ group in benzimidazole ring that remained unchanged after complexation which confirmed the non-coordination of this group ${ }^{15}$. Another band appears at the spectra of $\mathrm{Hg}(\mathrm{II})$ and $\mathrm{Zn}(\mathrm{II})$ complexes at $865-900 \mathrm{~cm}^{-1}$ due to $\mathrm{Cl}^{-}$vibration which support the involvement of $\mathrm{Cl}$ atom in complexation of these chelates. all these discussions indicate that the ligands are bidentate and coordinating via $\mathrm{O}, \mathrm{N}$ atoms.

\section{Mass spectra}

The mass spectral data did not show any of the required molecular ion peaks, but it could be deduced through studying of the assigned fragmentation peaks. All complexes have the same fragmentation, which have the main fragments [a], [b], [c], [d], [e], [f] at $\mathrm{m} / \mathrm{z}=180(4.5), 116(8.5)$, 90(10.2), 78(14), 50(50.3) and 64(36.2) (as fragments of ligand), which confirm the proposed structure of complexes. This was also confirmed by the appearance of a peak at 179.5(7.9), 127(2.8), 291.5(5.1) and 321(5.6) for fragments [g], [h], [i] and [j] respectively. The most prominent peaks were assigned as shown in the following fragmentation (Scheme.1).

\section{Thermal analysis}

The thermal behavior of the PNZ-Complexes was characterized using TGA/DTG method. The decomposition stages, temperature ranges and decomposition products as well as the found and calculated weight loss are given in Table (4). The activation energies and kinetic parameters were calculated using Coats-Redfern equation ${ }^{7}$ and the values are given in Table (5).

Cadmium complex undergo decomposition in four steps. Dehydration of the complex takes 
place in the $39-121^{\circ} \mathrm{C}$ range with DTG peak at $72^{\circ} \mathrm{C}$ associated with weight loss of $3.1 \%$ (Calcd. 3.86\%). Coordination sphere decomposition for the cadmium complex is concerned with the elimination of the

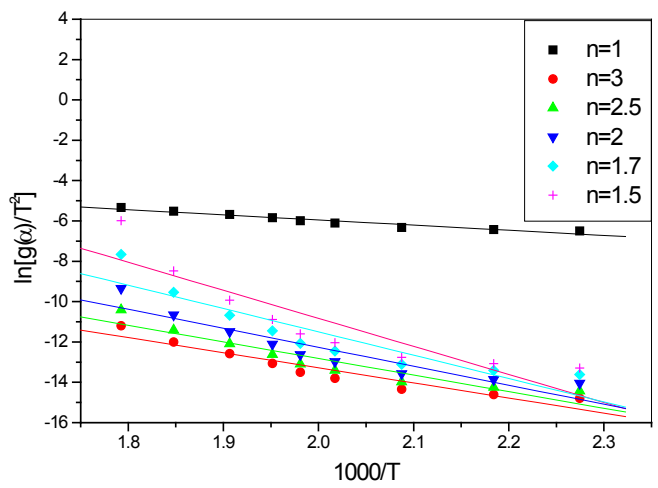

Fig.1: Linearization curves of $\left[\mathrm{Cd}(\mathrm{PNZ})_{2}\left(\mathrm{H}_{2} \mathrm{O}\right)_{2}\right]$ $\mathrm{H}_{2} \mathrm{O}$ complex (first decomposition step)

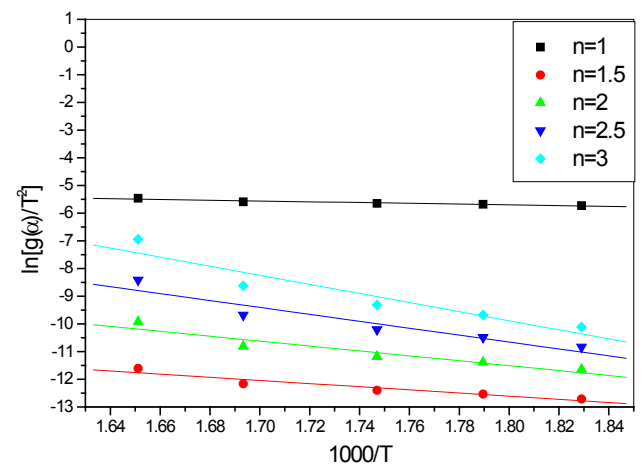

Fig.3: Linearization curves of $\left[\mathrm{Hg}(\mathrm{PNZ})\left(\mathrm{H}_{2} \mathrm{O}\right) \mathrm{Cl}\right]$ $\mathrm{H}_{2} \mathrm{O}$ complex (second decomposition step)

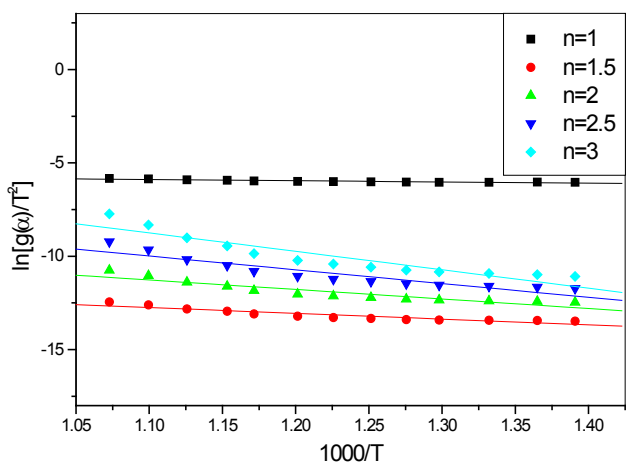

Fig. 5: Linearization curves of [ $\left.\mathrm{Zn}(\mathrm{PNZ})\left(\mathrm{H}_{2} \mathrm{O}\right) \mathrm{Cl}\right]$ $\mathrm{H}_{2} \mathrm{O}$ complex (first decomposition step) coordinated water and partial decomposition of the ligand. It takes place with DTG maxima at $233^{\circ} \mathrm{C}$ in the $120.4-302.9^{\circ} \mathrm{C}$ range. The ligand is continued to decompose at maxima 306.5 and $421.7^{\circ} \mathrm{C}$ in the

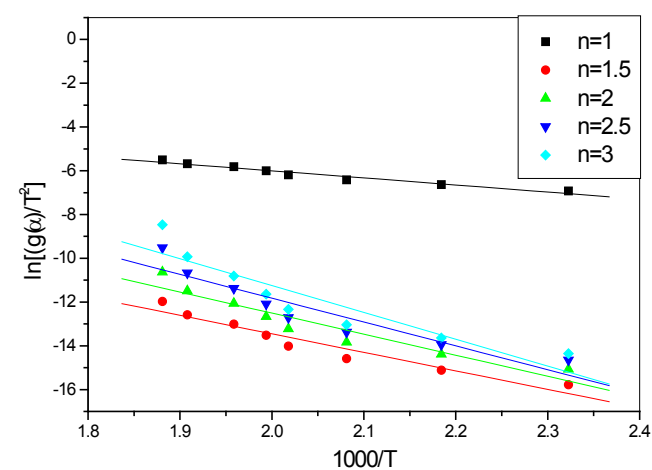

Fig. 2: Linearization curves of $\left[\mathrm{Hg}(\mathrm{PNZ})\left(\mathrm{H}_{2} \mathrm{O}\right)\right.$ $\mathrm{Cl}_{2} \mathrm{H}_{2} \mathrm{O}$ complex (first decomposition step)

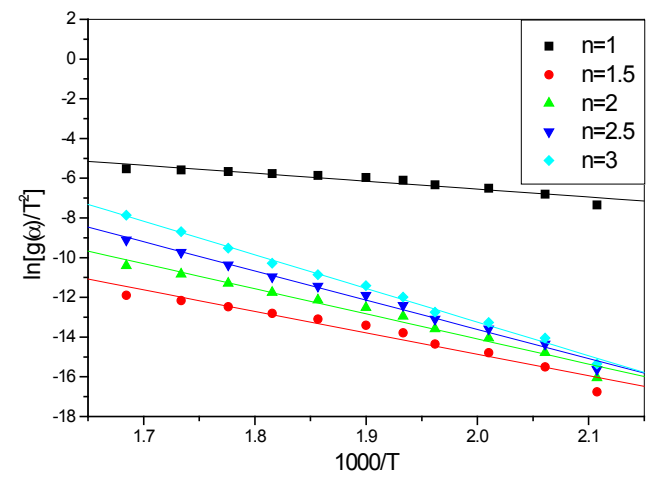

Fig.4: Linearization curves of $\left[\mathrm{Hg}(\mathrm{PNZ})\left(\mathrm{H}_{2} \mathrm{O}\right) \mathrm{Cl}\right]$ $\mathrm{H}_{2} \mathrm{O}$ complex (third decomposition step)

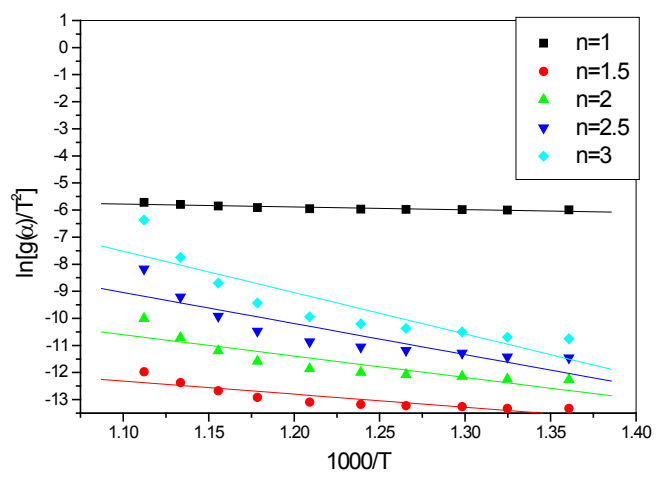

Fig. 6: Linearization curves of $\left[\mathrm{Zn}(\mathrm{PNZ})\left(\mathrm{H}_{2} \mathrm{O}\right) \mathrm{Cl}\right]$ $\mathrm{H}_{2} \mathrm{O}$ complex (second decomposition step) 
range of 302.9-388.7 and $388.7-801^{\circ} \mathrm{C}$, respectively with no definite final product since the decomposition process is not complete at $800{ }^{\circ} \mathrm{C}$.

TGA/DTG curves of the mercury complex are characterized by three decomposition steps. The first step takes place in the $35.4-256.7^{\circ} \mathrm{C}$ range with DTG peaks at 38.2 and $228^{\circ} \mathrm{C}$. Observed mass loss is $33.6 \%$ against calculated one of $33.1 \%$ corresponding evolution of crystallization water, coordinated water, chloride ion and partial decomposition of the ligand. The ligand is continued to decompose at $256.7^{\circ} \mathrm{C}$ and end with final decomposition at $398.4^{\circ} \mathrm{C}$. The final decomposition is attributed to the evaporation of $\mathrm{Hg}$ metal with

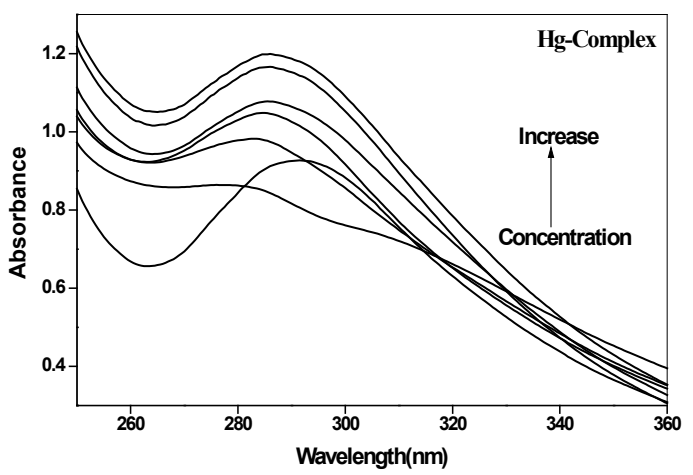

Fig. 7: Effect of concentration of DNA on the absorption band at $\lambda=293 \mathrm{~nm}(\mathrm{Hg}$-Complex $=$ $1 \times 10^{-4} \mathrm{molL}^{-1}$ )

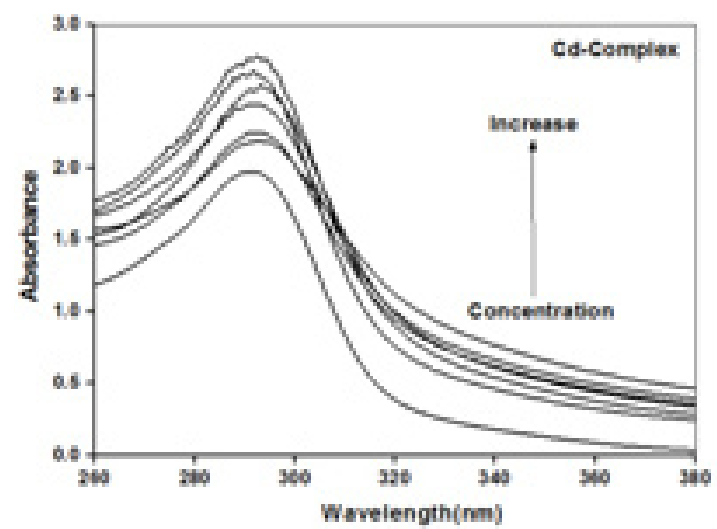

Fig. 8: Effect of concentration of DNA on the absorption band at $\lambda=293 \mathrm{~nm}$ (Cd-Complex $=$ $1 \times 10^{-4} \mathrm{molL}^{-1}$ ) weight loss of $33.8 \%$ against calculated one of $33.6 \%$. Carbon is remained as final product.

Thermal decomposition of zinc complex takes place in four stages. The first stage starts at 117.9-321.9 ${ }^{\circ} \mathrm{C}$ range. This was accompanied with mass loss of $30.3 \%$ (Calcd. 29.9\%) with maximum DTG at $228.5^{\circ} \mathrm{C}$, which attributed to the volatilization of the hydrated water, coordinated water, chloride ion and partial decomposition of the ligand. The second decomposition stage takes place in the $322.9-425.5^{\circ} \mathrm{C}$ range with maxima at $410^{\circ} \mathrm{C}$, which correspond decomposition of ligand. The third decomposition stage takes place at $426.4-506.4{ }^{\circ} \mathrm{C}$ range with maximum DTG at $491.6^{\circ} \mathrm{C}$ attributed to further decomposition of ligand with mass loss of 4.6\% (Calcd. 4.4\%). The final decomposition stage occurs in the range $506.9-797^{\circ} \mathrm{C}$ with maxima at 603 and $781^{\circ} \mathrm{C}$ with no definite final product since the decomposition process is not complete at $800{ }^{\circ} \mathrm{C}$.

From the TGA curves, the order $n$, activation energy $E$, and pre-exponential factor $A$ of the different thermal decomposition steps of the complexes have been elucidated by the method of Coats-Redfern? ${ }^{7}$. Some examples of the linearization curves for the complexes, which were obtained, presented in Figs. (1-6). The values of correlation coefficients of linearization curves of the complexes and their reaction orders are given in Table (5). The activation energy $E$ and enthalpy of activation $\Delta H$ of the three complexes are expected to increase proportional to decrease in their radii ${ }^{14}$. The activation energy of the

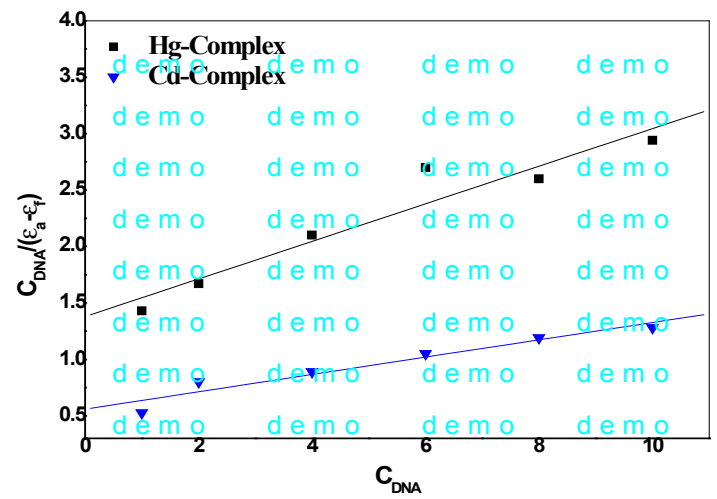

Fig. 9: Plot of [DNA] $/\left(\varepsilon_{\alpha}-\varepsilon_{f}\right)$ versus [DNA] 
tetrahedral $\left[\mathrm{Zn}(\mathrm{PNZ})\left(\mathrm{H}_{2} \mathrm{O}\right) \mathrm{Cl}\right] \mathrm{H}_{2} \mathrm{O}$ complex is higher than $\left[\mathrm{Hg}(\mathrm{PNZ})\left(\mathrm{H}_{2} \mathrm{O}\right) \mathrm{Cl}\right] \mathrm{H}_{2} \mathrm{O}$ complex.

The smaller the radius of metal ion, the easier the ligand approaches the central atom. As a result, metal-ligand interaction becomes stronger, the detachment of the link becomes more difficult and $E$ values increase ${ }^{15,16}$. The negative values of the entropies in the decomposition reactions of the complexes Table (5) indicates that the reactions are slower than normal ${ }^{17-19}$ and the activated complexes have more ordered structure than the reactants ${ }^{20,21}$.

Based on the above analytical data and physicochemical properties, the following structures are proposed in which the metal ion is coordinated through $\mathrm{C}-\mathrm{N}$, sulphonyl groups $\mathrm{S}=\mathrm{O}$, the coordinated water and the coordinated anion.

\section{DNA Interaction}

UV-Vis Absorption spectra (Figs. 7,8) were obtained by titration of $\left(1 \times 10^{-5}-1 \times 10^{-4} \mathrm{M}\right)$ complex solution with increasing concentration of DNA. In absence of DNA, the spectrum is characterized by a peak at $293 \mathrm{~nm}$. The absorbance of the peak increased gradually as DNA concentration increased.

The spectral changes reflect the corresponding changes in DNA in its conformation and structures after the drug bound to DNA. Intercalative mode of binding usually results in hypochromism and bathochromism due to strong stacking interaction between an aromatic chromophore and the base pairs of DNA. On the other hand, metal complexes which nonintercalatively or electrostatically bind with DNA may result in hyperchromism and hypsochromism. The absorption spectra show clearly that the addition of DNA to the complexes lead to strong hyperchromism accompanied by the slight hypsochromismto the [DNA]/[complex] (Fig. 9). Obviously, these spectral characteristics suggest that all the complexes interact with DNA via electrostatically with the base pairs of DNA ${ }^{22}$.

Table 1: Analytical data and magnetic moments of the PNZ and its complexes

\begin{tabular}{|c|c|c|c|c|c|c|c|}
\hline \multirow[t]{2}{*}{ Compound } & \multirow[t]{2}{*}{ Chemical formula } & \multicolumn{5}{|c|}{ \% Found (Calcd.) } & \multirow{2}{*}{$\begin{array}{c}\mu_{\text {eff. }}\left(298^{\circ} K\right) \\
\text { (B.M) }\end{array}$} \\
\hline & & C & $\mathbf{H}$ & $\mathbf{N}$ & S & M & \\
\hline PNZ & $\mathrm{C}_{16} \mathrm{H}_{14} \mathrm{~F}_{2} \mathrm{~N}_{3} \mathrm{O}_{4}$ S.Na.1.5 $\mathrm{H}_{2} \mathrm{O}$ & $\begin{array}{c}43.2 \\
(44.4)\end{array}$ & $\begin{array}{c}3.0 \\
(3.24)\end{array}$ & $\begin{array}{c}9.4 \\
(9.7)\end{array}$ & $\begin{array}{c}6.5 \\
(7.4)\end{array}$ & & \\
\hline Zn-PNZ & {$\left[\mathrm{Zn}(\mathrm{PNZ})\left(\mathrm{H}_{2} \mathrm{O}\right) \mathrm{Cl}\right] \mathrm{H}_{2} \mathrm{O}$} & $\begin{array}{c}36.3 \\
(36.97)\end{array}$ & $\begin{array}{c}3.2 \\
(3.47)\end{array}$ & $\begin{array}{c}8 \\
(8.08)\end{array}$ & $\begin{array}{c}5.8 \\
(6.16)\end{array}$ & $\begin{array}{c}12.1 \\
(12.5)\end{array}$ & Diamagnetic \\
\hline Cd-PNZ & {$\left[\mathrm{Cd}(\mathrm{PNZ})_{2}\left(\mathrm{H}_{2} \mathrm{O}\right)_{2}\right] \mathrm{H}_{2} \mathrm{O}$} & $\begin{array}{c}40.7 \\
(41.24)\end{array}$ & $\begin{array}{c}3.4 \\
(3.65)\end{array}$ & $\begin{array}{c}8.9 \\
(9.02)\end{array}$ & $\begin{array}{c}6.5 \\
(6.87)\end{array}$ & $\begin{array}{c}11.8 \\
(12.07)\end{array}$ & Diamagnetic \\
\hline $\mathrm{Hg}-\mathrm{PNZ}$ & {$\left[\mathrm{Hg}(\mathrm{PNZ})\left(\mathrm{H}_{2} \mathrm{O}\right) \mathrm{Cl}\right] \mathrm{H}_{2} \mathrm{O}$} & $\begin{array}{c}28.5 \\
(29.34)\end{array}$ & $\begin{array}{c}2.6 \\
(2.75)\end{array}$ & $\begin{array}{c}6.1 \\
(6.42)\end{array}$ & $\begin{array}{c}4.5 \\
(4.89)\end{array}$ & $\begin{array}{c}29.9 \\
(30.65)\end{array}$ & Diamagnetic \\
\hline
\end{tabular}

Table 2: Physical data of the PNZ ligand and its complexes

\begin{tabular}{|c|c|c|c|c|c|c|}
\hline Compound & Chemical formula & M. Wt & $\begin{array}{l}\% \\
\text { Yield }\end{array}$ & Color & $\begin{array}{c}\Lambda_{\mathrm{m}} \\
\left(\Omega^{-1} \mathrm{~cm}^{2} \mathrm{~mol}^{-1}\right)\end{array}$ & $\begin{array}{l}\text { Melting } \\
\text { Point }\left({ }^{\circ} \mathrm{C}\right)\end{array}$ \\
\hline PNZ & $\mathrm{C}_{16} \mathrm{H}_{14} \mathrm{~F}_{2} \mathrm{~N}_{3} \mathrm{O}_{4}$ S.Na.1.5 $\mathrm{H}_{2} \mathrm{O}$ & 432.38 & 82 & Off white & - & 137 \\
\hline Zn-PNZ & {$\left[\mathrm{Zn}(\mathrm{PNZ})\left(\mathrm{H}_{2} \mathrm{O}\right) \mathrm{Cl}\right] \mathrm{H}_{2} \mathrm{O}$} & 519.26 & 70 & Off white & 6 & 170 \\
\hline Cd-PNZ & {$\left[\mathrm{Cd}(\mathrm{PNZ})_{2}\left(\mathrm{H}_{2} \mathrm{O}\right)_{2}\right] \mathrm{H}_{2} \mathrm{O}$} & 931.16 & 73 & Faint brown & 5.4 & 160 \\
\hline $\mathrm{Hg}-\mathrm{PNZ}$ & {$\left[\mathrm{Hg}(\mathrm{PNZ})\left(\mathrm{H}_{2} \mathrm{O}\right) \mathrm{Cl}^{2}\right] \mathrm{H}_{2} \mathrm{O}$} & 654.47 & 62 & Faint red & 7 & 155 \\
\hline
\end{tabular}


In order to evaluate quantitatively the DNAbinding strength, the intrinsic DNA-binding constants, $\mathrm{Kb}$ of the complexes have been estimated to be in the range $[0.121-0.382 \mathrm{~mol} / \mathrm{L}]$ and is are listed in the Table (6).

\section{pH-metric Measurements}

The formation of various 1:1:1 ternary complex species are inferred from the potentiometric$\mathrm{pH}$ titration curves. Initial estimates of the stability constants of the resulting species and the acid dissociation constants of pantoprazole, and amino acids have been refined with the HYPERQUAD computer program ${ }^{23}$. The quality of the fit during this refinement was judged by the values of the sample standard deviations and the goodness of fit $\chi^{2}$ (Pearson's Test). At $\sigma_{E}=0.1 \mathrm{mV}(0.001 \mathrm{pH}$ error $)$ and $\sigma_{\mathrm{v}}=0.005 \mathrm{~cm}^{3}$, the values of $S$ in different sets of titrations were between 1.0 and 1.7 and $\chi^{2}$ was between 12.0 and 13.0. The scatter of residuals $\left(E_{\text {obs }}-E_{\text {calc }}\right)$ versus $\mathrm{pH}$ reasonably random, without any significant systematic trends, thus indicating a good fit of the experimental data of the expected model systems under our experimental conditions. Furthermore, the formation constants values of the different 1:1 metal ion- amino acids have been determined under identical conditions. This is made with the aim to compare the stability of the formed $1: 1: 1$ ternary complex with of the corresponding $1: 1$ binary metal complexes.

All the initial estimates of the formation constants of the different binary and ternary complexes formed in the present investigation have been refined using HYPERQUAD computer program.

$$
K_{M(P N Z)(A A)}=\frac{\left[M_{p}(P N Z)_{q}(A A)_{\mathrm{r}}\right]}{\left[M_{P}(P N Z)_{q}\right][A A]^{I}}
$$

Which refers to the addition of amino acids to the binary complex $M_{p}(P N Z)_{q}$. The overall complexation reaction involving protonation is,

$$
\begin{aligned}
& \mathrm{pM}+\mathrm{q} P N Z+\mathrm{r} A \mathrm{~A}+\mathrm{sH} \rightleftharpoons \mathrm{M}_{\mathrm{p}}(\mathrm{PNZ})_{\mathrm{q}}(\mathrm{AA})_{\mathrm{r}}(\mathrm{H})_{\mathrm{s}} \\
& \beta_{\mathrm{pers}}=\frac{\mathrm{M}_{\mathrm{p}}(\mathrm{PNZ})_{\mathrm{q}}(\mathrm{AA})_{\mathrm{q}}(\mathrm{H})_{\mathrm{s}}}{[\mathrm{M}]^{\mathrm{p}}[\mathrm{PNZ}]^{\mathrm{q}}[\mathrm{L}]^{\mathrm{s}}[\mathrm{H}]^{\mathrm{s}}}
\end{aligned}
$$

Which, $A A=$ amino acids, $P N Z=$ Pantoprazole, $M=C d(I I), Z n(I I)$.

The data points collected in the $\mathrm{pH}$ range 3.0-11.0 were used for the calculations and refinements. The formation constants of all the binary and the ternary complexes studied are given in Tables $(7,8)$.

The $\mathrm{pH}$-metric titration curves in case of PNZ ligand before the acid curve indicating that in acidic solutions each molecule of the ligand is in association with one equivalent of proton. This proton should be attached with the lone pair of electrons present on the nitrogen of the ring in the case of PNZ. PNZ shows one step acid dissociation due to deprotonation of one secondary amine group.

$$
\mathrm{LH} \leftrightarrow \mathrm{L}^{-}+\mathrm{H}^{+}
$$

Representative set of experimental titration curves, obtained according to the sequence for different $\mathrm{M}-\mathrm{PNZ}$ reveals that below $\mathrm{pH} 7.5$ formation of different M-PNZ binary complexes take place. This is clear from the appeared divergence of each of the 1:1 binary M-PNZ titration curve from that of the corresponding free PNZ curve. Binary complexes are stable up to $\mathrm{pH} \mathrm{5-8} \mathrm{in} \mathrm{case} \mathrm{of}$ different metal ions. Hydrolysis of the complexes leads to the formation of hydroxo-complex species. The nature of the $\mathrm{pH}$ titration curves indicates that stepwise complex formation take place through deprotonation of secondary amine group. The acid dissociation constant value are for pantoprazole $(\mathrm{pKa}=6.2 \pm 0.02)^{5}$. The acid dissociation constant values for amino acids are in good agreement with those found in the literature ${ }^{24}$.

Of the $20 \alpha$-amino acids that commonly occur in proteins; about half contain side chain donor atoms that are at least potentially capable of forming a chelate ring with metal ion bound at the $\alpha$-amino nitrogen. If the $\alpha$-amino and $\alpha$-carboxylate groups that occur in the free amino acids also chelate the metal ion, then two chelate rings will be formed.

The order of stability constants of $M+P N Z$ + Alanine is $\mathrm{Cd}>\mathrm{Zn}$.

Phenylalanine, as its name indicates, contains a phenyl ring attached in place of one of the 


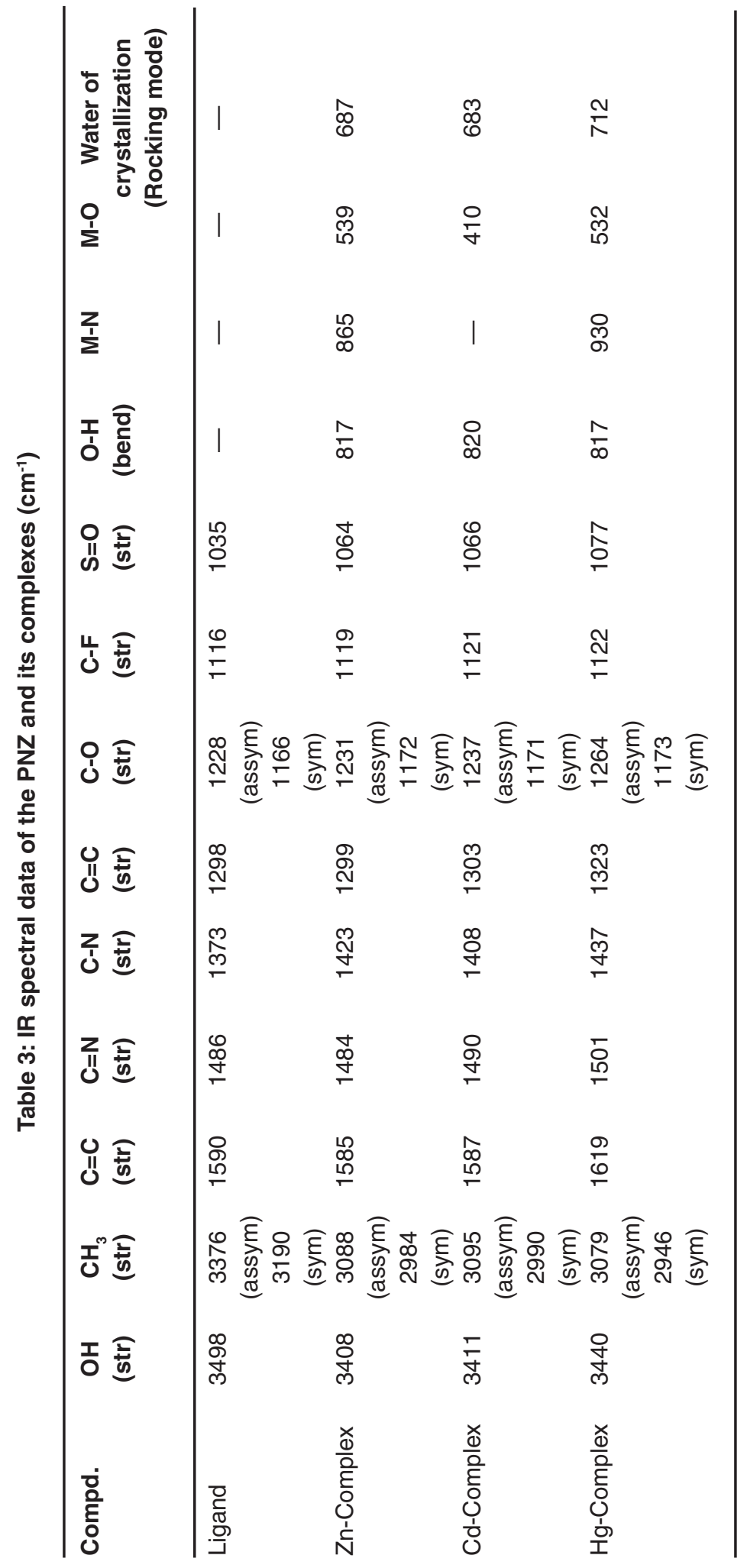


HEGAZY et al., Orient. J. Chem., Vol. 32(2), 1085-1097 (2016)

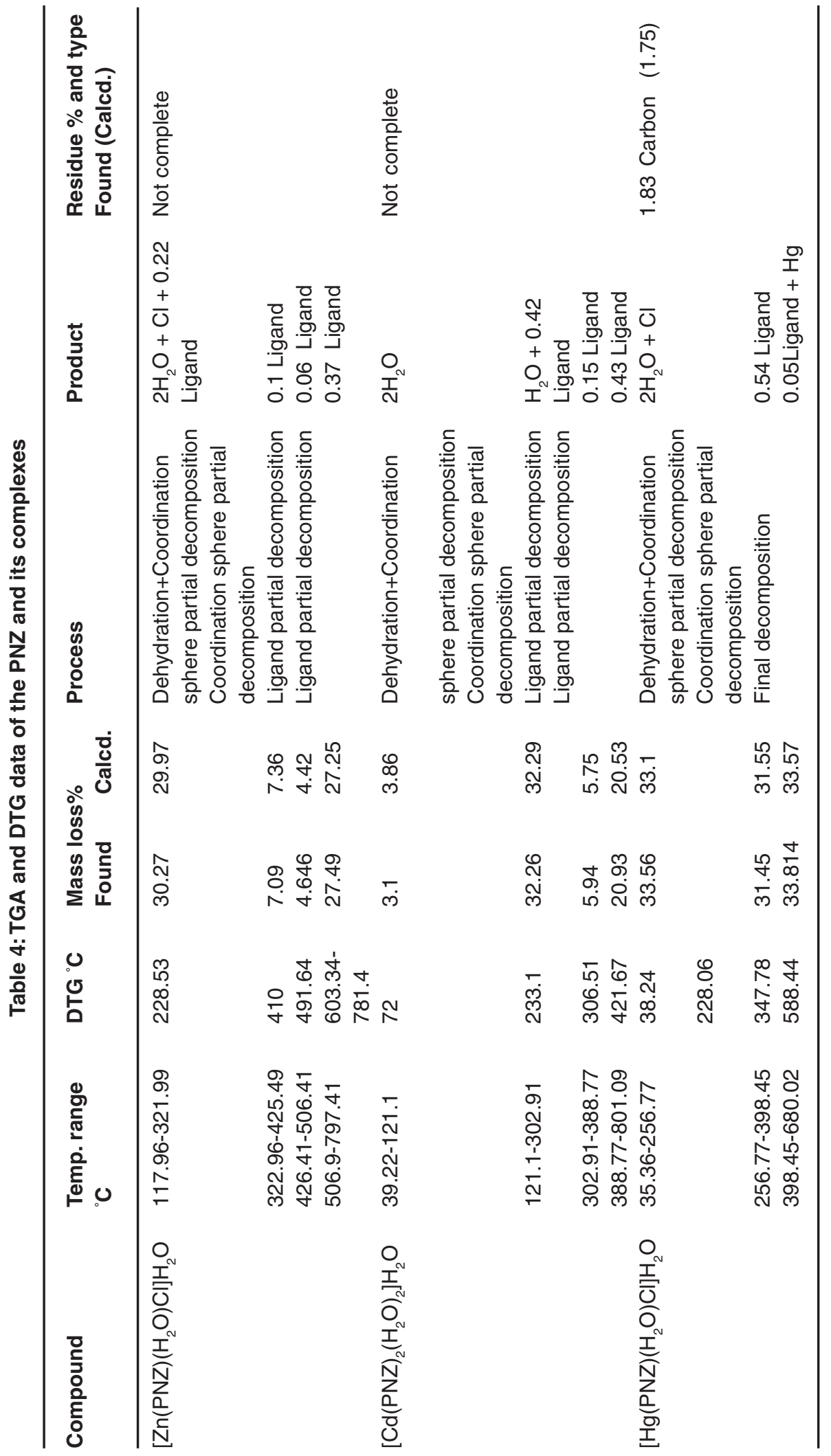


hydrogen of alanine. The order of stability constants of $\mathrm{M}+\mathrm{PNZ}+$ Phenylalanine is $\mathrm{Zn}>\mathrm{Cd}$.

Aspartic acid contains two acidic side chains. This amino acid is often called aspirate to emphasize that its side chain is usually negatively charged at physiological $\mathrm{pH}$. The order of stability constants of $\mathrm{M}+\mathrm{PNZ}+$ Aspartic acid is $\mathrm{Cd}>\mathrm{Zn}$.

The amino acid histidine in its dicationic form contains four acidic protons. As the $\mathrm{pH}$ increased the successive pKa values for potone removal are carboxylic acid imidazolium. $-\mathrm{N}(3)-\mathrm{H}$, side chain ammonium imidazole $-\mathrm{N}(1)-\mathrm{H}$. The imidazole (1)-NH is very weakly acidic $(\mathrm{pKa}=14.4)$ and thus it does not dissociate in the measureable $\mathrm{pH}$ range. It has been argued strongly that metal ion binding on the aromatic imidazole ring occurs only at pyridine nitrogen, as the energy required for binding to occur at a pyrrole nitrogen is prohibitive ${ }^{25}$. The order of stability constants of $\mathrm{M}+\mathrm{PNZ}+$ Histidine is $\mathrm{Zn}>\mathrm{Cd}$.

Threonine contains aliphatic hydroxyl group. It can be thought of as hydroxylated version of valine with hydroxyl group in place of one of the valine

Table 5: Kinetic parameters for the first decomposition step of the PNZ-complexes

\begin{tabular}{|c|c|c|c|c|c|c|c|c|}
\hline Comp. & Step & $\mathbf{E}$ & A & $\mathbf{n}$ & $\mathbf{R}$ & $\Delta \mathbf{H}$ & $\Delta \mathbf{G}$ & $\Delta \mathbf{S}$ \\
\hline \multirow{2}{*}[\mathrm{Zn}(\mathrm{PNZ})(\mathrm{H}_{2}\mathrm{O})\mathrm{Cl}]{$\mathrm{H}_{2} \mathrm{O}$} & 1 & 324.2186 & $1.03 E+16$ & 3 & 0.9977 & 320.0488 & 291.3221 & 57.2781 \\
\hline & 2 & 92.07861 & 3432.793 & 1.5 & 0.8861 & 83.31232 & 281.2472 & -187.723 \\
\hline$\left[\mathrm{Cd}(\mathrm{PNZ})_{2}\left(\mathrm{H}_{2} \mathrm{O}\right)_{2}\right] \mathrm{H}_{2} \mathrm{O}$ & 1 & 48.86083 & 859168.6 & 1.5 & 0.9717 & 44.65311 & 113.3337 & -135.706 \\
\hline \multirow{3}{*}[\mathrm{Hg}(\mathrm{PNZ})(\mathrm{H}_{2}\mathrm{O})\mathrm{Cl}]{$\mathrm{H}_{2} \mathrm{O}$} & 1 & 61.81923 & 3828334 & 1 & 0.9772 & 57.65342 & 119.3837 & -123.199 \\
\hline & 2 & 26.67542 & 36056564 & 1 & 0.9651 & 21.51425 & 87.52501 & -106.335 \\
\hline & 3 & 189.056 & 57501102 & 3 & 0.9273 & 181.894 & 272.4992 & -105.179 \\
\hline
\end{tabular}

$\mathrm{E}, \Delta \mathrm{H}, \Delta \mathrm{G}$ in $\mathrm{KJ}_{\mathrm{mol}}{ }^{-1}$

$\Delta S$ in $\mathrm{J} \mathrm{mol}^{-1} \cdot \mathrm{k}^{-1}$

$A$ in $S^{-1}$

Table 6: The Binding constant of complexes with DNA

\begin{tabular}{lccc}
\hline Complex & $\begin{array}{c}\text { Binding } \\
\text { constant (Kb) }\end{array}$ & $\mathbf{R}$ & SD \\
\hline Hg-PNZ & 0.121 & 0.9596 & 0.1904 \\
Cd-PNZ & 0.137 & 0.9685 & 0.0769 \\
\hline \multicolumn{3}{l}{ R = Correlation coefficients } \\
SD = Standard deviations
\end{tabular}

methyl groups. The hydroxyl groups of threonine make them much more hydrophilic and reactive than valine ${ }^{26}$. As the alcoholic hydroxy group is so weakly acidic ( $\mathrm{pKa}>14$ ) that is does not undergo dissociation. The order of stability constants of $\mathrm{M}+$ $\mathrm{PNZ}+$ Threonine is $\mathrm{Zn}>\mathrm{Cd}$.

Cystein contains three dissociable protons, the last two of these deprotonations, those of the ammonium and the thiol groups take place

Table 7: Formation constants for the binary $M+$ amino acids (AA) and $\mathrm{M}-\mathrm{PNZ}$ ligand complexes at $25 \pm 0.1^{\circ} \mathrm{C}$ and $\mathrm{I}=0.1 \mathrm{~mol}^{-1} \mathrm{KNO}_{3}$

\begin{tabular}{lccccccc}
\hline $\begin{array}{l}\text { Metal } \\
\text { lons }\end{array}$ & $\log _{M(A l a)}$ & $\log _{M(P h e)}$ & $\log _{M(A s p)}$ & $\log _{M(T h r)}$ & $\log _{M(H i s)}$ & $\log _{M(C y s)}$ & $\log _{M(P N Z)}$ \\
\hline Cd (II) & $4.12 \pm 0.02$ & $4.11 \pm 0.03$ & $5.86 \pm 0.02$ & $4.16 \pm 0.02$ & $3.98 \pm 0.04$ & $8.89 \pm 0.02$ & $6.21 \pm 0.03$ \\
Zn (II) & $5.81 \pm 0.02$ & $4.96 \pm 0.02$ & $6.97 \pm 0.02$ & $4.9 \pm 0.02$ & $4.94 \pm 0.02$ & $8.45 \pm 0.03$ & $7.15 \pm 0.02$ \\
\hline
\end{tabular}


Table 8: Formation Constants for $\mathrm{M}+$ Pantoprazole (PNZ) + Amino Acids (AA) 1:1:1 Ternary Complexes at $25.0 \pm 0.1^{\circ} \mathrm{C}$ and $\mathrm{I}=0.1 \mathrm{~mol}^{\mathrm{L}} \mathrm{L}^{-1}$

\begin{tabular}{lcccccc}
\hline Metal ion & $\log _{M(A \mathrm{Ala})(\mathrm{PNZ})}$ & $\log _{\mathrm{M}(\mathrm{Phe})(\mathrm{PNZ})}$ & $\log _{\mathrm{M}(\mathrm{Asp})(\mathrm{PNZ})}$ & $\log _{\mathrm{M}(\mathrm{Thr})(\mathrm{PNZ})}$ & $\log _{\mathrm{M(His)(PNZ)}}$ & $\log _{\mathrm{M(Cys}(\mathrm{PNZ})}$ \\
\hline $\mathrm{Cd}(\mathrm{II})$ & $15.47^{\mathrm{b}} \pm 0.02$ & $2.18^{\mathrm{a}} \pm 0.02$ & $19.11^{\mathrm{b}} \pm 0.02$ & $1.96^{\mathrm{a}} \pm 0.02$ & $1.56^{\mathrm{a}} \pm 0.02$ & $19.58^{\mathrm{b}} \pm 0.02$ \\
$\mathrm{Zn}(\mathrm{II})$ & $3.91^{\mathrm{a}} \pm 0.02$ & $3.59^{\mathrm{a}} \pm 0.02$ & $17.83^{\mathrm{b}} \pm 0.03$ & $3.91^{\mathrm{a}} \pm 0.02$ & $2.89^{\mathrm{a}} \pm 0.02$ & $18.29^{\mathrm{b}} \pm 0.03$ \\
\hline
\end{tabular}

in overlapping processes. Cystein is typical ambidentate ligand, the possible metal binding sites are different in nature. $\mathrm{COO}^{-}$is rather hard, $\mathrm{S}^{-}$is fairly soft and $\mathrm{NH}_{2}$ is borderline. The $-\mathrm{SH}$ and $-\mathrm{NH}_{3}{ }^{+}$groups have relatively high $\mathrm{pKa}$ values, and the sulfur atoms behaves as bridging ligands. Thus a great variety of metal complexes may be formed, including protonated and polynuclear complexes with monodentate and different bidentate and tridentate bonding modes. The order of stability constants of $\mathrm{M}+\mathrm{PNZ}+$ Cystein is $\mathrm{Cd}>\mathrm{Zn}$.

The observed different orders may be attributed to different types of interactions depending on metal ion different geometrical behavior during the formation of binary and ternary complexes in solution.

\section{CONCLUSION}

From elemental analysis it can be concluded that the formula of the $\mathrm{Zn}^{2+}$ and $\mathrm{Hg}^{2+}$ complexes can be represented as $\left[\mathrm{M}(\mathrm{PNZ})\left(\mathrm{H}_{2} \mathrm{O}\right) \mathrm{Cl}\right] \mathrm{H}_{2} \mathrm{O}$, while $\mathrm{Cd}^{2+}$ represented as $\left[\mathrm{Cd}(\mathrm{PNZ})_{2}\left(\mathrm{H}_{2} \mathrm{O}\right)_{2}\right] \mathrm{H}_{2} \mathrm{O}$, the molar conductance for the complexes were measured in DMF and showed that PNZ-complexes are nonelectrolytes. From magnetic susceptibility and UV spectroscopy it's found that Zn-PNZ, Cd-PNZ and $\mathrm{Hg}-\mathrm{PNZ}$ complexes are diamagnetic where $\mathrm{Zn}$ and $\mathrm{Hg}$ have tetrahedral geometry, while $\mathrm{Cd}$ have octahedral geometry. IR spectra for ligand and its complexes showed that the pantoprazole act as bidentate ligand which form complexes with metals through $\mathrm{C}-\mathrm{N}$ and $\mathrm{S}=\mathrm{O}$ groups, also the spectra showed new peaks due to $\mathrm{M}-\mathrm{N}$ and $\mathrm{M}-\mathrm{O}$ which confirmed the involvement of $\mathrm{N}$ and $\mathrm{O}$ atoms in complexation with metal ions. The mass spectral data showed that three complexes formed with molar ratio $M: L=1: 2$. Thermal analysis showed the different decomposition stage of the metal complexes, which appear the presence of water of hydration in all complexes. The activation energy $\mathrm{E}$ and enthalpy of activation $\Delta \mathrm{H}$ of the complexes are expected to increase proportional to decrease in their radii.

\section{REFERENCES}

1. Yogita, B.; Om, S. Bioorg. Med. Chem.1995, 20, 6208-6236.

2. Suman, M.; Supriya, D.; Bharti, J. RJPBCS 2010, 1, 394-400.

3. Mohamed; G. G.; Ibrahim, N. A.; Attia, H. A. Spec. chim. Acta A 2009, 72, 610-615.

4. Tiwari, C. R. Search Res. 2011, 3, 24-28.

5. Tiwari, C. R. JERAD 2012, 6, No. 3A.

6. Figgis, B. N.; Lewis, J.: in Lewis, J.; Wilkins, R. G. (Eds.) 1960 Magnetochemistry of complex compounds in Modern Coordination chemistry, Interscience, New York.

7. Coats, A.W.; Redfern, J. P. Nature 1964, 68, 201.

8. Cotton, F. A.; Wilkinson, G.; Murillo, C.
A.; Bochmann, M. Advanced Inorganic Chemistry, Sixth Ed. 1999 Wiley, New York.

9. Koley M. K.; Sivasubramanian S. C.; Varghese B.; Manoharan P. T.; Koley A. P. Inorg. Chim. Acta 2008, 361, 1485.

10. Wolfe A.; Shimer G. H.; Meehan T. Biochem. 1987, 26, 6392.

11. Mohamed, G. G.; El-Gamel, N. E. A.; Nour El-Dien, F. A. Synth. React. Inorg. Met.-Org. Chem. 2001, 31, 347.

12. Kohout, J.; Hvastijova, M.; Kozisek, J.; Diaz, J. G.; Valko, M.; Jager, L.; Svoboda, I. Inorg. Chim. Acta 1999, 287, 186.

13. Uçan, S.Y.; Uçan, M.; Mercimek, B. Synth. React. Inorg. Met.-Org. Chem. 2005, 35, 417- 
421.

14. Sari, N.; Gurkan, P.; Arslan, S. Transit. Met. Chem. 2003, 28, 468-474.

15. Shyamala, B. S.; Lakshmi, P. V. A.; Raju, V. J. J. Sci. Res. 2010, 2, 525-537.

16. Silverstein, R. M.; Webster F. X. Spectrometric identification of organic compounds 2007 Wiley interscience, India, Delhi, 102.

17. Sallam S. A. Trans. Met. Chem. 2006, 31, 46.

18. Sangari, H. S.; Sodhi, S. Thermo Chim. Acta 1990, 171, 49.

19. Styczen, E.; Warnke, Z.; Wyrzykowski, D. Thermo Chim. Acta 2007, 454, 84.

20. Indria, V.; Parameswaran, G. J. Therm. Anal. 1993, 39, 1417.
21. Frost, A. A.; Pearson, R. G. Kinetics and Mechanicsm 1961, Wiley interscience, New York.

22. Nagababu, P.; Naveena, J.; Latha, L.; Prashanthi, Y.; Satyanarayana, S. J. Chem. Pharm. Res. 2009, 1, 238.

23. Gans, P.; Vacca, A. J. Talanta 1996, 43, 1739.

24. Martell, A. E; Smith, R. M. Critical Stability Constants 1975, vol. 1and 2, Plenum Press, New York.

25. Sundberg, R. J.; Martin, R. S. Chem. Rev. 1974, 74, 471.

26. Berg, J. M.; Tymoczko, J. L.; Stryer, L. The Molecular Design of Life-Protein Structure and Function 2003, Biochemistry, Fifth Edition. 